\title{
The Persistent Organic Pollutants of Dioxins in Egypt
}

\author{
Saad M Magdy* \\ Department of Food Safety \& Contamination, National Research Centre, Egypt
}

Submission: April 13, 2017; Published: April 28, 2017

"Corresponding author: Saad M Magdy, Department of Food Safety \& Contamination, National Research Centre, 33 El Buhouth St. Ad Doqi, Dokki Cairo Governorate, Egypt, Email: madgdy_saad6@yahoo.com

\section{Introduction}

Referring to the Stockholm C [1] dealing with the persistent organic pollutants "POP's", both polychlorinated dibenzo-dioxins and furans (PCDD's \& PCDF's) were considered chemical hazards including 210 tricyclic congeners. The number of positional congeners is quite large, due to the number and position of chlorine atoms ( 1 to 8 ) forming 75 PCDD's and 135 PCDF's with different range of toxic effects. The most potent congener of $2,3,7,8$ polychlorinated dibenzo dioxin was considered in the quantitative assay to express the total concentration of contamination in terms of pg I-TEQ/ gm fat.

Recently, it is well established that PCDD's and PCDF's are formed as trace amounts of environmental pollutants during the manufacture processes of advanced industries, commonly related and limited to the industrial countries Malish [2]. Exposure to PCDD/F's in the general population mainly occurred through the food chain, moreover, some individuals occupationally engaged to certain industries which might leads to dermal contact and inhalation routes of exposure Wu et al. [3]. PCDD/ F's as lipophilic molecules are predominantly stored in fat and adipose tissues and excreted in milk and vital organs at lower concentrations Khin et al. [4].

In the general population, it's common to report PCDD/F's concentrations up to $20 \mathrm{ug} / \mathrm{kg}$ body eight, with no known specific exposure, while higher levels of PCDD?F's have been detected in some cases without evidence of any diseases Malisch [5]. PCDD's and PCDF's are persistent pollutants in the environment and they could bioaccumulate and have long half-life in humans WHOEuro [6]. Thus, the repeated low-dose exposure to such hazards could substantially increase in body burden level equivalent to a single high dose exposure. In other words, exposure to either high or low dosages of PCDD's/ PCDF's had the same risk due to the long half-life of such hazards [3].

PCDD's and PCDF's as Persistent Organic Pollutants in Egypt

A cooperative scientific work between the National Research Centre "NRC" of Egypt and Dioxins Lab. of State Institute of
Chemical and Veterinary analysis of food "CLUA", Freiburg, Germany was proceeded to search for PCDD/F's in food samples of processed meat products, butter, margarine and fresh water fish of river Nile. Moreover, the project concerned to participate in round 3 of the EU-WHO project searching for PCDD's and PCDF's in samples collected from mothers donating breast milk from 22 interested country. The prolonged project which extends to more than 8 years revealed that PCDD's and PCDF's did not represent a significant problem in Egypt. The major obstacle in this work is the high and expensive cost of sample analysis, to jump over such problem, pooled samples were employed, each analyzed breast milk sample collected from 45 nursing mothers, while each pooled food sample and/ or fish involved 5 individuals. It's worthy to start with the data obtained from mother's milk. Data showed that the levels of PCB's contamination were ranged between 4.43-8.26 pg/g fat Malisch [7].

Fortunately, such levels of PCB's contamination are within the corresponding results of samples obtained from the participated developed countries of Canada, Franc, Germany, UK and USA [6]. Regarding to the levels of PCDD's and PCDF's contamination, data exhibited that only 2 out of 9 pooled samples were little pit higher than the detected average of the participated countries being $15.05 \mathrm{pg} / \mathrm{I}-\mathrm{TEQ} / \mathrm{g}$ fat. The lowest and accepted values of contamination were observed in samples of mothers living in rural areas of Upper Egypt consuming less amounts of food of animal origin and fish, not exceed 2 times a week.

It should be noticed that all samples collected from the 22 participating countries involved round $3 \mathrm{EU}-\mathrm{WHO}$ project were analyzed in the same accredited and reference lab. Of CLUA, Freiburg, Germany which means that all obtained results had the same accuracy, precision and uncertainty of measurement. The prolonged project was extended to search for dioxins in some fatty foods including processed meat products, butter, margarine and local kinds of fresh water fish. The obtained data showed that the analyzed meat products purchased from Egyptian markets had concentration levels of PCDD's and PCDF's not only within the permissible limits established by EU, but also less than the 
corresponding means of many similar kinds of food consumed in Europe.

Regarding butter and margarine samples, data showed wide range of variation of PCDD's/F's contamination, based on the district source of samples. Only one butter sample out of eight showed high level of contamination (28.9pg I-TEQ/g fat), while the margarine samples revealed neglible traces of both PCDD's and PCDF's Saad [8]. According to the 2 kinds of river Nile fish previously collected from different locations on Nile shores.

Data revealed that PCDD's and PCDF's concentrations were varied widely and ranged between 2.77 to $27.34 \mathrm{pg}$ I-TEQ/g fat. Such wide range of variation distributed between the 2 studied variables, the location on Nile shore and kind of fish. The more fatty kind of Cat fish exhibited about 4 folds of PCDD/F's concentrations comparing with the less fatty Tilapia fish [7]. Thus, it could be concluded that the persistent pollutants of PCDD's and PCDF's did not represent a significant or prioritized problem in Egyptian environment.

\section{References}

1. Stockholm (2004) Press release about the convention and agreement. Bazel Action Network, USA.

2. Malisch R (2003) The levels of PCB's, PCDD's and PCDF's in human milk. J of Organohalogen compounds 56: 140-145.

3. Wu Y, Li J, Zhao Y, Chen Z, Chen J (2002) Dietary intake of Polychlorinated dibenzo-dioxins (PCDD's) in breast milk. Copenhagen FADL Publishers, Europe.

4. Khin P, Cheung S, Joh T (2002) Support and promotion of breast Feeding. Bull of Public Health Epid 11: 25-32.

5. Malisch R (2005) Analysis, exposure and metabolism of PCDD's/ PCDF's Presentation in the Nat. Res Centre, Egypt.

6. WHO-Euro (2004) Levels of PCB's, PCDD's and PCDF's in human milk. Final Report of exposure studies. Bonn WHO Europen Center for environment and health, Germany.

7. Malisch R, Fouzy A, Saad M (2000) PCDD/F in human milk and River Nile from Egypt. J of Organo halogen Compounds 48: 5-10.

8. Saad MM (2006) Polychlorinated di-benzo-dioxins/ furans as Persistent organic pollutants. Egypt J of Biomedical Science 21: 109125.

\section{Your next submission with Juniper Publishers} will reach you the below assets

- Quality Editorial service

- Swift Peer Review

- Reprints availability

- E-prints Service

- Manuscript Podcast for convenient understanding

- Global attainment for your research

- Manuscript accessibility in different formats

( Pdf, E-pub, Full Text, Audio)

- Unceasing customer service

Track the below URL for one-step submission https://juniperpublishers.com/online-submission.php 